\title{
EKSPERIMENTASI METODE TADRIB DALAM MENINGKATKAN PEMAHAMAN MAHASISWA TERHADAP AL-KALIMAH DALAM BAHASA ARAB
}

Hastang

Institut Agama Islam Negeri Bone, Indonesia e-mail: hastang_annur81@yahoo.com

\begin{abstract}
مجرد
إستهدف هذا البحث إلى معرفة الإنتاج من تجربة الطريقة التدريبية في تحسين فهم الظّلبة ب"الكلمة" فى

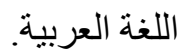

قد كان هذا البحث وصفيا نوعيا. امّا سكّانه هو طلبة|الفصل الدراسي الأول من السنة الدّراسية

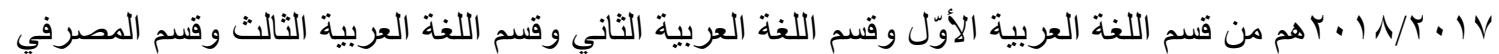
الإسلامي السادس بأخذ العينات من قسم اللغة العربية الأول. وان البيانات المجموعة من خلاله تمت عن الطريق الإختباري و المر اقبي و المقابلي مع نشاط العمل و التوثيق والملاحظة. ثم إن البيانات المجموعة خلال هذا البحث حلات تحليلا نو عيا.

ودلّت نتائج البحث على: (1) يستطيع الطلاب أن يبينوا عن بيانان الكلمة و أقسامه و علاماته و أمثاله. (Y) بعض الطلاب قادرون علي تحديد وإظهار الكلمة باللغة العربية نفسياونشيطا. نظرا للتحركات المذكورة. ييدو أن نتائج من تجربة الطريقة التدريبي مناسبة بغرض تعليم كلمة اللغة

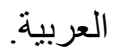
الكلمات الرئيسية: الطريقة التدريبية و الفهم و الكلمة في اللغة العربية
\end{abstract}

\section{Pendahuluan}

Mempelajari bahasa Arab merupakan fardu kifayah, sebagaimana perkataan Ibnu Taimiyah Rokhimahullah: "Diketahui sesungguhnya belajar bahasa Arab dan mengajarkannya adalah fardlu kifayah". Dan beliau juga berkata: " Sesungguhnya bahasa Arab adalah agama, dan mengetahuinya adalah fardlu (wajib), dan sesungguhnya pemahaman kitab dan sunnah adalah fardlu, dan tidak bisa difahami kecuali dengan bahasa Arab, dan sesuatu yang wajib tidak akan terselesaikan kecuali dengan yang wajib maka hukumnya adalah wajib"1. Oleh karena bahasa Arab bukan hanya sekedar sebagai bahasa komunikasi melainkan sebagai bahasa Al-Quran, hadits, dan kitab-kitab yang merupakan penjelasan kedua sumber hukum Islam

${ }^{1}$ Arsyad, Azhar. Bahasa Arab dan Metode Pengajarannya. Cet. III; (Yogyakarta: Pustaka Pelajar, 2010), h.3 
tersebut ${ }^{2}$ sehingga dapat dikatakan bahwa bahasa Arab merupakan modal dasar untuk dapat memahami Islam dan segala ajarannya. Hal inilah yang mejadi salah satu dasar pemikiran untuk menjadikan bahasa Arab sebagai pelajaran penting di semua jenjang pendidikan yang berciri khas Islam, mulai dari Madrasah Ibtidaiyah, Madrasah Tsanawiyah, Madrasah Aliyah, maupun Perpendidikan Tinggi. Bahkan sekarang bahasa Arab sudah menjadi mata pelajaran pilihan di sebagian SMA dan Perpendidikan Tinggi Umum.

Melihat kedua aspek tersebut, maka mempelajari bahasa Arab memiliki dua arah, yaitu menguasai keterampilan bahasa Arab dan menguasai ilmu bahasa Arab. Keterampilan bahasa Arab disebut juga dengan maharah al-lughah yang terdiri atas empat, yaitu maharah al-istima' (keterampilan mendengar), maharah al-kalam (keterampilan berbicara), maharah al-qiraah (keterampilan membaca), dan maharah alkitabah (keterampilan menulis). Sedangkan ilmu bahasa Arab memiliki beberapa cabang ilmu diantaranya adalah ilmu balaghah, ilmu arudh, ilmu mantiq, serta ilmu nahwu dan ilmu sharaf. Ilmu nahwu adalah ilmu tentang kaidah-kaidah Bahasa Arab, untuk mengetahui bentuk kata dan keadaan-keadaannya ketika masih satu kata (Mufrod) atau ketika sudah tersusun (Murokkab). Sedangkan ilmu sharaf adalah ilmu yang membahas tentang perubahan bentuk kata (Bahasa Arab: Al-Kalimah). Perubahan bentuk kata ini dalam prakteknya disebut Tashrif. Oleh karena itu dinamakan Ilmu Sharaf (perubahan; berubah), karena Ilmu ini khusus membahas mengenai Tashrif (pengubahan; mengubah).

Berdasarkan pengertian dari ilmu nahwu dan ilmu sharaf tersebut dapat disimpulkan bahwa dasar pembahasan ilmu ini adalah pembahasan tentang kata. Sehingga langkah awal dari pembelajaran ilmu nahwu dan sharaf adalah pengenalan kata dalam bahasa arab yang biasa disebut dengan Al-Kalimah. Dengan kata lain bahwa Al-Kalimahmerupakan materi dasar dan pokok dalam mempelajari bahasa Arab. Pembahasan tentang Al-Kalimahmemiliki cakupan yang cukup luas, secara umum dibagi menjadi 3, yaitu al-Ism, al-fi'il, al-Harf . al-Ism dapat diartikan sebagai kata benda/ pronoun. Al-Fi'il diartikan sebagai kata kerja atau verba, sedangkan al-Harf diartikan sebagai preposisi.

Sebagai dasar dalam penguasaan ilmu bahasa Arab dan juga dasar dalam penguasaan keterampilan bahasa Arab, Al-Kalimah menjadi materi yang wajib dipelajari, dipahami, dan dikuasai oleh peserta didik beserta dengan berbagai macam bentuk dan perubahannya. Disamping karena hal ini adalah hal yang sangat fundamental, hasil observasi awal menunjukkan bahwa pengetahuan awal mahasiswa tentang Al-Kalimahsangatlah minim dikarenakan salah satu penyebabnya adalah latar belakang pendidikan mahasiswa yang tidak pernah belajar bahasa Arab, materi tentang

${ }^{2}$ Shaleh, M. Kilat Pintar Bahasa Arab. Cet.I; (Jogjakarta: Laksamana, 2013), h.7 
bahasa Arab menjadi hal yang sangat baru bagi sebagian besar dari mereka. Dengan demikian dibutuhkan metode khusus dalam memaksimalkan pencapaian pemahaman dan penguasaan materi ini. Penelitian ini bertujuan untuk meningkatkan pemahaman mahasiswa terhadap Al-Kalimahdalam bahasa Arab melalui metode yang tepat. Sehingga penelitian ini dapat bermanfaat dalam pengembangan ilmu pengetahuan, menambah khasanah kajian ilmiah dalam pengembangan metode pembelajaran.

\section{Pengertian Metode Tadrib}

Metode tadrib yang disebut juga dengan metode training yaitu merupakan suatu cara kebiasaan tertentu. Juga sarana untuk memelihara kebiasaan yang baik. Selain itu, metode ini juga dapat digunakan untuk ketangkasan, ketepatan, kesempatan dan ketrampilan. ${ }^{3}$ Pengertian metode tadrib menurut beberapa pendapat memiliki arti sebagai berikut:

a. Roestiyah N.K, Suatu teknik yang dapat diartikan sebagai suatu cara mengajar peserta didik melakukan kegiatan latihan, peserta didik memiliki ketangkasan dan keterampilan lebih tinggi dari apa yang dipelajari. ${ }^{4}$

b. Zuhairini, Suatu metode dalam pendidikan dan pengajaran dengan jalan melatih peserta didik terhadap bahan pelajaran yang sudah diberikan. ${ }^{5}$

c. Shalahuddin, Suatu kegiatan dalam melakukan hal yang sama secara berulangulang dan sungguh-sungguh dengan tujuan untuk menyempurnakan suatu keterampilan supaya menjadi permanen. ${ }^{6}$

Dari beberapa pendapat di atas, dapat disimpulkan bahwa metodetadribadalah metode berupa latihan dengan praktek yang dilakukan berulang kali secara kontinyu untuk mendapatkan keterampilan dan ketangkasan praktis tentang pengetahuan yang dipelajari. Dari segi pelaksanaannya peserta didik terlebih dahulu telah dibekali dengan pengetahuan secara teori. Kemudian dengan tetap dibimbing oleh pendidik, peserta didik diminta mempraktikkannya sehingga menjadi mahir dan terampil.

\section{Macam-macam Metode tadrib}

Bentuk-bentuk Metode tadrib dapat direalisasikan dalam berbagai bentuk teknik, yaitu sebagai berikut:

a. Teknik kerja kelompok

Teknik ini dilakukan dengan caramembentuk beberapa kelompok untuk bekerja sama dalam memecahakan masalah dengan cara mengerjakan tugas yang diberikan.

b. Teknik Micro Teaching

Digunakan untuk mempersiapkan diri peserta sebagai calon pendidik untuk menghadapi pekerjaan mengajar di depan kelas dengan memperoleh nilai pengetahuan, kecakapan dan sikap sebagai pendidik.

c. Teknik Modul Belajar

\footnotetext{
${ }^{3}$ Syaiful Bahri Djamarah dan Aswan Zain, Strategi Belajar Mengajar (Jakarta: PT. Rineka Cipta, 1996), 108

${ }^{4}$ Roestiyah NK., Strategi Belajar Mengajar (Jakarta: Bina Aksara, 1985), h.103

${ }^{5}$ Zuhairini, dkk, Metodik Khusus Pendidikan Agama (Surabaya: Usaha Nasional, 1983), h.106

${ }^{6}$ Shalahuddin, Metodologi Pengajaran Agama, (Surabaya: Bina Ilmu, 1987), h.100
} 
Digunakan dengan cara mengajar peserta didik melalui paket belajar.

d. Teknik Belajar Mandiri

Dilakukan dengan cara meminta peserta didik agar belajar sendiri dan tetap dalam bimbingan pendidik, baik dalam kelas maupun di luar kelas. ${ }^{7}$

\section{Tujuan Penggunaan Metode Tadrib}

Metode tadribbiasanya digunakan agar peserta didik:

a. Memiliki kemampuan menghafalakan kata-kata, menulis, mempergunakan alat.

b. Mengembangkan kecakapan intelek, seperti mengalikan, membagi, menjumlahkan. ${ }^{8}$

c. Memiliki kemampuan menghubungkan antara sesuatu keadaan dengan yang lain.

d. Untuk memperoleh suatu ketangkasan, keterampilan tentang sesuatu yang dipelajari peserta didikdengan melakukannya secara praktis pengetahuan yang telah dipelajari. Dan siap dipergunakan bila sewaktu-waktu diperlukan. ${ }^{9}$

\section{Hal yang Harus Diperhatikan dalam penerapan metode tadrib}

Ada beberapa hal yang harus diperhatikan dalammenggunakan metode ini, yaitu:

a. Tujuan harus dijelaskan kepada peserta didik sehingga mereka dapat mengerjakan latihan dengan tepat sesuai apa yang diharapkan.

b. Tentukan dengan jelas kebiasaan yang dilatihkan sehingga peserta didik mengetahui apa yang harus dikerjakan.

c. Lama latihan disesuaikan dengan kemampuan peserta didik.

d. Selingilah latihan dengan penjelasan agar tidak membosankan.

e. Perhatikan kesalahan umum yang dilakukan peserta didik untuk perbaikan. ${ }^{10}$

Pembimbing perlu memperhatikan nilai dari latihan itu sendiri serta kaitannya dengan keseluruhan pembelajaran. Dalam persiapan sebelum memasuki latihan, pendidik harus memberikan pengertian dan perumusan tujuan yang jelas kepada peserta didik, sehingga mereka mengetahui tujuan latihan yang akan diterimanya. Persiapan yang baik sebelum latihan dapat memotivasi peserta didik agar menjadi aktif dalam melaksanakan pembelajaran.

Metode tadribmemiliki kelebihan sebagai berikut:

a. Mengkokohkan daya ingatan peserta didik, karena seluruh pikiran, perasaan, kemauan dikonsentrasikan pada pelajaran yang dilatihkan.

b. Peserta dapat menggunakan daya fikirnya dengan baik, dengan pengajaran yang baik, maka peserta didik menjadi lebih teliti.

c. Adanya pengawasan, bimbingan dan koreksi yang segera serta langsung dari Pendidik.

\footnotetext{
${ }^{7}$ Muhaimin Abdul Mujib, Pemikiran Pendidikan Islam, (Bandung: Trigenda Karya, 1993), h.226-228

${ }^{8}$ Roestiyah NK., Strategi Belajar Mengajar, h.125-126

${ }^{9}$ Pasaribu dan Simandjuntak, Didaktikdan Metodik (Bandung: Tarsito, 1986), h.112

${ }^{10}$ Winarno Surakhmad, Pengantar Interaksi Belajar Mengajar. (Bandung: Tarsito, 1994), h.92.
} 
d. Pesertaakan memperoleh ketangkasan dan kemahiran dalam melakukan sesuatu sesuai dengan apa yang dipelajarinya. ${ }^{11}$

e. Pendidik bisa lebih mudah mengontrol dan dapat membedakan mana peserta yang paham dan yang tidak.

f. Pemanfaatan kebiasaan yang tidak memerlukan konsentrasi yang tinggi dalam pelaksanaannya serta dapat membentuk kebiasaan yang baik.

g. Pengertian peserta lebih luas melalui latihan berulang-ulang ${ }^{12}$.

Dengan adanya berbagai kelebihan dari penggunaan metode tadribini maka diharapkan bahwa latihan dapat bermanfaat bagi peserta didik untuk menguasai materi. Serta dapat menumbuhkan pemahaman untuk melengkapi penguasaan pelajaran yang diterima secara teori dan praktek.

\section{Kelemahan Metode Tadribdan Cara Mengatasinya}

Sebagai suatu metode yang diakui banyak mempunyai kelebihan, juga tidak dapat dipungkiri bahwa metodetadribjuga mempunyai kelemahan, yaitu:

a. Latihan yang dilakukan dibawah pengawasan yang ketat dan suasana serius mudah sekali menimbulkan kebosanan.

b. Latihan yang selalu diberikan dibawah bimbingan dan perintahPendidik dapat melemahkan inisiatif maupun kreatifitas peserta.

c. Kadang-kadang latihan yang dilaksanakan secara berulang-ulang merupakan hal yang monoton dan mudah membosankan. ${ }^{13}$

Maka dari itu, pendidik yang ingin mempergunakan metode ini ada baiknya memahami karakteristik metode ini terlebih dahulu. Akan tetapi ada beberapa cara untuk mengatasi kelemahan-kelemahan tersebut, yaitu:

a. Janganlah seorang pendidik menuntut dari peserta suatu respons yang sempurna.

b. Jika terdapat kesulitan pada peserta pada saat merespon, hendaknya pendidik segera meneliti penyebabnya.

c. Berikanlah segera penjelasan-penjelasan, baik respon yang betul maupun yang salah.

d. Usahakan peserta memiliki ketepatan merespon kemudian kecepatan merespon.

e. Istilah-istilah baik berupa kata maupun kalimat yang digunakan dalam latihan hendaknya dimengerti oleh peserta didik. ${ }^{14}$

\section{Tinjauan tentang Pemahaman}

Beberapa definisi tentang pemahaman telah diungkapkan oleh para ahli. Menurut Nana Sudjana, pemahaman adalah hasil belajar, misalnya peserta didik dapat menjelaskan dengan susunan kalimatnya sendiri atas apa yang dibacanya atau

\footnotetext{
${ }^{11}$ Winarno Surakhmad, Pengantar Interaksi Belajar Mengajar. (Bandung: Tarsito, 1994), h. 94

${ }^{12}$ Syaiful Bahri Djamarah dan Aswan Zain, Strategi Belajar Mengajar, h.108-109

${ }^{13}$ Syaiful Bahri Djamarah dan Aswan Zain, Strategi Belajar Mengajar, h.108

${ }^{14}$ Syaiful Bahri Djamarah dan Aswan Zain, Strategi Belajar Mengajar, h.108-109
} 
didengarnya, memberi contoh lain dari yang telah dicontohkan pendidik dan menggunakan petunjuk penerapan pada kasus lain. ${ }^{15}$

Menurut Winkel dan Mukhtar pemahaman adalah kemampuan seseorang untuk menangkap makna dan arti dari bahan yang dipelajari, yang dinyatakan dengan menguraikan isi pokok dari suatu bacaan atau mengubah data yang disajikan dalam bentuk tertentu kebentuk yang lain. Pemahaman berarti pula memperkembangkan kesadaran akan faktor-faktor yang penting.

Jadi, dapat disimpulkan bahwa seorang peserta didik dikatakan memahami sesuatu apabila ia dapat memberikan penjelasan atau memberi uraian yang lebih rinci tentang hal yang dia pelajari dengan menggunakan bahasanya sendiri. Lebih baik lagi apabila dapat memberikan contoh atau mensinergikan apa yang dia pelajari dengan permasalahan-permasalahan yang ada di sekitarnya. Dalam hal ini, peserta didik dituntut untuk memahami atau mengerti apa yang diajarkan, mengetahui apa yang sedang dikomunikasikan dan dapat memanfaatkan isinya tanpa keharusan untuk menghubungkan dengan hal-hal yang lain.

\section{Indikator Pemahaman}

Indikator pemahaman menunjukkan bahwa pemahaman mengandung makna lebih luas atau lebih dalam dari pengetahuan. Dengan pengetahuan, seseorang belum tentu memahami sesuatu secara mendalam, hanya bisa mengetahui tanpa bisa menangkap makna dan arti dari sesuatu yang dipelajari. Sedangkan dengan pemahaman, seseorang tidak hanya bisa menghafal sesuatu yang dipelajari, tetapi juga mempunyai kemampuan untuk menangkap makna dari sesuatu yang dipelajari juga memahami konsep dari pelajaran tersebut.

Peserta didik dapat dikatakan memahami suatu materi jika memenuhi beberapa indikator. Indikator dari pemahaman itu sendiri yaitu:
a. Mengartikan
b. Memberikan contoh
c. Mengklasifikasi
d. Menyimpulkan
e. Menduga
f. Membandingkan
g. Menjelaskan. ${ }^{16}$

\section{Tingkatan-Tingkatan dalam Pemahaman}

Pemahaman merupakan salah satu patokan kompetensi yang dicapai setelah peserta didik melakukan kegiatan belajar. Dalam proses pembelajaran, setiap individu peserta didikmemiliki kemampuan yang berbeda beda dalam memahami apa yang

\footnotetext{
${ }^{15}$ Nana Sudjana, Dasar-Dasar Proses Belajar Mengajar, h.100

${ }^{16}$ Wowo Sunaryo K, Taksonomi Kognitif (Bandung: PT Remaja Rosdakarya, 2012), h.117
} 
dipelajari. Ada yang mampu memahami materi secara menyeluruh dan ada pula yang sama sekali tidak dapat mengambil makna dari apa yang telah dipelajari, sehingga yang dicapai hanya sebatas mengetahui. Untuk itulah terdapat tingkatan-tingkatan dalam memahami. Kemampuan pemahaman berdasarkan tingkat kepekaan dan derajat penyerapan materi dapat dijabarkan ke dalam tiga tingkatan, yaitu: ${ }^{17}$

a. Menerjemahkan (translation)

Pengertian menerjemahkan bisa diartikan sebagai pengalihan arti dari bahasa yang satu ke dalam bahasa yang lain. Dapat juga dari konsepsi abstrak menjadi suatu model simbolik untuk mempermudah orang mempelajarinya.

b. Menafsirkan (interpretation)

Kemampuan ini lebih luas daripada menerjemahkan, ini adalah kemampuan untuk mengenal dan memahami. Menafsirkan dapat dilakukan dengan cara menghubungkan pengetahuan yang lalu dengan pengetahuan yang diperoleh berikutnya, menghubungkan antara grafik dengan kondisi yang dijabarkan sebenarnya, serta membedakan yang pokok dan tidak pokok dalam pembahasan.

c. Mengekstrapolasi (extrapolation)

Ekstrapolasi menurut kemampuan intelektual yang lebih tinggi karena seseorang dituntut untuk bisa melihat sesuatu dibalik yang tertulis. Membuat ramalan tentang konsekuensi atau memperluas persepsi dalam arti waktu, dimensi, kasus, ataupun masalahnya.

\section{Tinjauan Tentang Al-Kalimah}

Al-Kalimah adalah suatu lafaz yang digunakan untuk menunjukan makna yang bersifat mufrod/tunggal. Jika Al-Kalimah dalam bahasa arab di bahasa indonesiakan maka disebut kata. Kalimat dibagi menjadi 3, yaitu isim, fi' $i l$ dan harf.

Isim adalah Adalah Al-Kalimah yang menunjukan pada arti pada dirinya sendiri tanpa tidak disertai oleh waktu, fi'iladalahAl-Kalimah yang menunjukan pada arti pada dirinya sendiri yang disertai oleh waktu melakukannya, harf merupakan Al-Kalimah yang menunjukan pada arti bukan pada dirinya sendiri.

Pembagian isim dapat ditinjau dari beberapa aspek, yaitu 1). Aspek Jenisnya terbagi menjadi Ism Muzakkar dan Ism Muannas, 2) Aspek jumlahnyanya terbagi menjadi Ism Mufrad, Ism Musanna, dan Ism Jamak, 3) Aspek kejelasannya terbagi menjadi Ism Ma'rifah dan Ism Nakirah, 4) Aspek perubahan harakat huruf akhir terbagi menjadi Ism Mu'rab dan Ism Mabni.

Demikian juga halnya dengan $f i$ 'il yang memiliki pembagian berdasarkan aspekaspeknya. 1) Aspek waktunya, terbadi menjadi fi'il madhy, fi'il mudhari', dan fi 'il Amr, 2) Aspek Hurufnya terbagi menjadi fi'il shahih dan fi'il mu'tal, 3) Aspek kebutuhan terhadap Maf'ul terbagi menjadi fi'il lazim dan fi'il muta'addy. Termasuk juga didalam pembahasan Al-Kalimah adalah tashrif fi'il yang dikenal dengan istilah tashrif lughawy dan tashrif ishtilahy.

\footnotetext{
${ }^{17}$ Nana Sudjana, Dasar-Dasar Proses Belajar Mengajar., h.124-125
} 
Adapun pembahasa tentang harf hanya terbatas pada huruf al-jar, huruf al-nasb, dan huruf al-jazm.

\section{Penggunaan Metode Tadrib Dalam Meningkatkan Pemahaman Mahasiswa Terhadap Al-KalimahDalam Bahasa Arab}

Metode tadrib diawali dengan metode ceramah sebagai langkah awal pembelajaran dan pengantar materi yang akan diajarkan. Pada fase ini dosen menjelaskan seputar pokok pembahasan yang disertai dengan contoh, baik yang masih berbentuk kata maupun dalam bentuk kalimat. Selanjutnya adalah tahap tanya jawab, mahasiswa diberikan kesempatan untuk menanyakan materi yang belum dimengerti. Misalnya pada pertemuan pertama membahas tentangisim. Langkah awal yang dilakukan adalah menjelaskan mengenai pengertian isim, pembagian-pembagiannya, serta ciri-cirinya. setelah mahasiswa menanyakan hal-hal yang belum dimengerti, mereka dilatih untuk mengidentifikasi isim berdasarkan ciri-ciri yang telah dijelaskan dari bacaan yang disiapkan sebelumnya, mahasiswa diminta untuk menyebutkan ciriciri isim yang telah ditemukan.

Yang paling penting adalah setiap mahasiswa diberi kesempatan untuk menampilkan hasil pekerjaannya baik berupa lisan ataupun berupa tulisan dan ditutup dengan pembahasan bersama mengenai jawaban yang tepat.

Pada pertemuan kedua, membahas mengenai pembagian isimberdasarkan jenisnya yang terbagi menjadi isim muzakkar dan isim muannas, yang mencakup ciriciri dari masing-masing keduanya, cara mengidentifikasi keduanya, dan cara pembentukan isim muzakkar menjadi isim muannas.

Setelah selesai sesi tanya jawab dilanjutkan latihan. Mahasiswa diberi tugas/ latihan dalam bentuk: 1) mengidentifikasi isim muzakkar dan muannas dalam sebuah bacaan, 2) menjelaskan ciri-ciri muzakkar dan muannas dari bacaan yang sudah diidentifikasi, 3) membentuk menjadi muannas dari mufradat yang sudah disiapkan.

Pada pertemuan ketiga, membahas tentang pembagian isim berdasarkan jumlahnya yang terbagi menjadi isim mufrad, isim musanna, dan isim jamak. Terlebih dahulu perkuliahan diawali dengan pengantar mengenai ketiga jenis isim tersebut, ciricirinya, pembagian jamak, cara penerjemahannya, cara membentuk isim mufrad menjadi musanna dan jamak.

Demikian tahapan-tahapan penggunaan metode ini dalam pembelajaran $\mathrm{Al}$ Kalimah. Pembahasan Al-Kalimah diselesaikan dengan 14 kali pertemuan dengan rincian materi seperti yang telah disebutkan diatas. Hal yang sangat subtansial adalah mahasiswa diberi latihan/tadribuntuk memberi penguatan atas penjelasan sebelumnya sehingga diharapkan pemahaman mahasiswa terhadap materi ini dapat meningkat. 
Efektifitas Metode Tadrib dalam Meningkatkan Pemahaman Mahasiswa

\section{Terhadap AL-KALIMAH dalam Bahasa Arab}

Berdasarkan hasil unjuk kerja, sebagian besar mahasiswa mampu menyelesaikan latihan yang telah diberikan, baik latihan secara tertulis ataupun lisan. Meskipun kadang kala masih ada yang perlu pendampingan dari dosen. Diantaranya menjelaskan pengertian, menyebutkan ciri-ciri dan pembagiannya, mengidentifikasi jenis Al-Kalimah dalam bacaan, menjelaskan tentang pembagian Al-Kalimah dari berbagai aspek, merubah Al-Kalimah dari satu bentuk kedalam bentuk yang lain, serta mampu menemukan contoh Al-Kalimah berdasarkan penjelasan sebelumnya.

Selain itu ada peningkatan pemahaman mahasiswa setelah diberi latihan secara berulang-ulang. Hasil unjuk kerja tersebut dapat dilihat pada tabel berikut:

Tabel.1.1 Hasil Unjuk Kerja Mahasiswa Dalam Memahami Al-Kalimah

\begin{tabular}{|c|c|c|c|c|c|c|}
\hline \multirow[b]{2}{*}{$\mathrm{NO}$} & \multirow[b]{2}{*}{ NAMA } & \multicolumn{3}{|c|}{ INDIKATOR } & \multirow[b]{2}{*}{$\begin{array}{c}\text { RATA } \\
- \\
\text { RATA }\end{array}$} & \multirow[b]{2}{*}{$\begin{array}{c}\text { KET } \\
\cdot\end{array}$} \\
\hline & & $\begin{array}{c}\text { IDENTIFI } \\
\text { KASI } A L- \\
K A L I M A \\
H\end{array}$ & $\begin{array}{c}\text { MENEMUKA } \\
\mathrm{N} \text { CONTOH } \\
A L-K A L I M A H\end{array}$ & $\begin{array}{c}\text { MEMBENT } \\
\text { UK } A L- \\
\text { KALIMAH }\end{array}$ & & \\
\hline 01. & $\begin{array}{ll}\text { Altrie } & \text { Syamsia } \\
\text { Narti } & \end{array}$ & 90 & 70 & 70 & 77 & \\
\hline 02. & Hamsiah & 95 & 90 & 90 & 92 & \\
\hline 03. & Arman Ibrahim & 85 & 80 & 70 & 78 & \\
\hline 04. & Asmaul Husna & 90 & 90 & 95 & 92 & \\
\hline 05. & $\begin{array}{ll}\text { Annisa } & \text { Rizki } \\
\text { Salsabila } & \end{array}$ & 95 & 90 & 90 & 92 & \\
\hline 06. & $\begin{array}{l}\text { Muhammad Yunus } \\
\text { Amin }\end{array}$ & 80 & 70 & 70 & 73 & \\
\hline 07. & Nurul Afifah & 90 & 80 & 80 & 84 & \\
\hline 08. & Agil Tamril & 70 & 65 & 65 & 67 & \\
\hline 09. & $\begin{array}{l}\text { Aulia } \quad \text { Nurfaisa } \\
\text { Jafar }\end{array}$ & 90 & 80 & 80 & 85 & \\
\hline 10 . & Nurul Aisyah & 90 & 90 & 95 & 92 & \\
\hline 11. & Nur Azaima & 80 & 80 & 80 & 80 & \\
\hline 12. & Nurmadaliah & 95 & 95 & 95 & 95 & \\
\hline 13. & Efi Dafriani & 85 & 80 & 80 & 82 & \\
\hline 14. & Wahyuni & 95 & 90 & 90 & 92 & \\
\hline 15. & Nurul Hidayah & 80 & 70 & 70 & 73 & \\
\hline 16. & Muh. Azlam Syah & 85 & 70 & 70 & 75 & \\
\hline 17. & Muh. Nur Iswan & 85 & 70 & 70 & 75 & \\
\hline 18. & Risal Renaldi & 70 & 70 & 70 & 70 & \\
\hline
\end{tabular}




\begin{tabular}{|l|l|c|c|c|c|c|}
\hline 19. & Akmal Asman & 95 & 95 & 95 & 95 & \\
\hline 20. & $\begin{array}{l}\text { Muh. Nurkhalis } \\
\text { Zainal }\end{array}$ & 90 & 85 & 85 & 87 & \\
\hline 21. & Sri Wahyuni & 90 & 85 & 80 & 85 & \\
\hline
\end{tabular}

Table diatas menunjukkan bahwa sebagian besar mahasiswa sudah mampu memahami Al-Kalimah dalam bentuk tadrib mengidentifikasi Al-Kalimah, membuat contoh Al-Kalimah, dan merubah bentuk Al-Kalimah.

Sementara hasil wawancara menunjukkan bahwa dari latihan-latihan yang ditugaskan membantu memahami materi yang telah dijelaskan. Sebagian mahasiswa mengatakan bahwa "kami baru mengerti setelah lebih sering latihan melalui identifikasi kata ataupun membentuk kata". Sebagian lagi mengatakan bahwa "istilah-istilah $\mathrm{Al}$ Kalimah yang asing lebih kami kenal dan paham melalui latihan-latihan baik secara lisan maupun tulisan.

\section{Simpulan}

Berdasarkan data yang diperoleh dari instrumen yang digunakan, metodetadribsangat relevan dengan cara pencapaianpembelajaran tentangAl-Kalimah dalam bahasa Arab sehingga dalam ekperimen ini membuktikan bahwa metode ini sangat tepat diterapkan dalam pembelajaran al-Kalimah. Dan sebagai pertimbangan langkah-langkah yang sudah dijelaskan. Hal itu terlihat pada kemampuan mahasiswa menyelesaikan tugas-tugas yang diberikan. Selain itu adanya peningkatan pemahaman mahasiswa sebelum dan sesudah latihan diberikan.

\section{Daftar Pustaka}

Abdul Mujib, Muhaimin, Pemikiran Pendidikan Islam. Bandung: Trigenda Karya, 1993. Ahmad, Abu, Metode Khusus Pendidikan Agama. Bandung: CV. Amrico, 1986. 8 Djamarah, Syaiful Bahri dan Aswan Zain, Strategi Belajar Mengajar. Jakarta: PT. Rineka Cipta, 1996.

Djamarah, Syaiful Bahri, dan Aswan Zain, Strategi Belajar Mengajar, Jakarta: PT. Rineka Cipta, 1996

Hermawan, Acep. Metodologi Pembelajaran Bahasa Arab. Cet.III; Bandung: PT. Remaja Rosda Karya, 2013.

N.K, Roestiyah, Strategi Belajar Mengajar. Jakarta: Bina Aksara, 1985.

Pasaribu dan Simandjuntak, Didaktikdan Metodik. Bandung: Tarsito, 1986.

Shalahuddin, Metodologi Pengajaran Agama. Surabaya: Bina Ilmu, 1987.

Sudjana,Nana, Dasar-Dasar Proses Belajar Mengajar. Bandung: Sinar Baru, 1991.

Sunaryo K, Wowo, Taksonomi Kognitif. Bandung: PT Remaja Rosdakarya, 2012.

Surakhmad, Winarno, Pengantar Interaksi Belajar Mengajar. Bandung: Tarsito, 1994.

Zuhairini, dkk, Metodik Khusus Pendidikan AgamA. Suarabaya: Usaha Nasional, 1983. 